\title{
Are typical radiators over-dimensioned? An analysis of radiator dimensions in 1645 Danish houses
}

\section{Østergaard, Dorte Skaarup; Svendsen, Svend}

\section{Published in:}

Energy and Buildings

Link to article, DOI:

10.1016/j.enbuild.2018.08.035

Publication date:

2018

Document Version

Peer reviewed version

Link back to DTU Orbit

Citation (APA):

Østergaard, D. S., \& Svendsen, S. (2018). Are typical radiators over-dimensioned? An analysis of radiator dimensions in 1645 Danish houses. Energy and Buildings, 178, 206-215.

https://doi.org/10.1016/j.enbuild.2018.08.035

\section{General rights}

Copyright and moral rights for the publications made accessible in the public portal are retained by the authors and/or other copyright owners and it is a condition of accessing publications that users recognise and abide by the legal requirements associated with these rights.

- Users may download and print one copy of any publication from the public portal for the purpose of private study or research.

- You may not further distribute the material or use it for any profit-making activity or commercial gain

- You may freely distribute the URL identifying the publication in the public portal 


\section{Accepted Manuscript}

Are typical radiators over-dimensioned? An analysis of radiator dimensions in 1645 Danish houses

Dorte Skaarup Østergaard, Svend Svendsen

PII:

DOI:

Reference:

S0378-7788(18)31702-X

https://doi.org/10.1016/j.enbuild.2018.08.035

ENB 8771

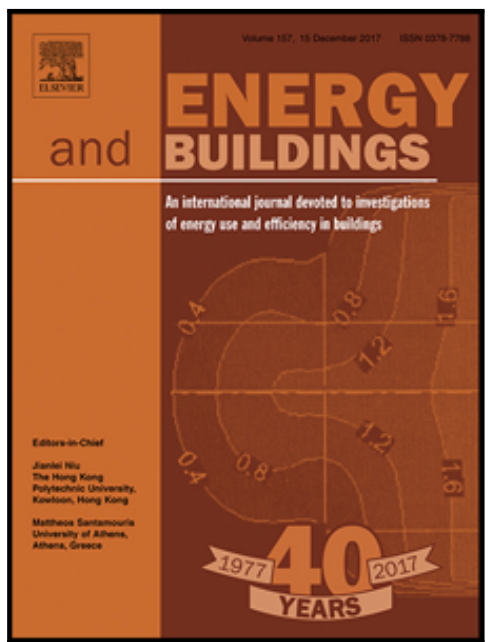

To appear in:

Energy \& Buildings

Received date:

4 June 2018

Revised date:

31 July 2018

Accepted date:

20 August 2018

Please cite this article as: Dorte Skaarup Østergaard, Svend Svendsen, Are typical radiators overdimensioned? An analysis of radiator dimensions in 1645 Danish houses, Energy \& Buildings (2018), doi: https://doi.org/10.1016/j.enbuild.2018.08.035

This is a PDF file of an unedited manuscript that has been accepted for publication. As a service to our customers we are providing this early version of the manuscript. The manuscript will undergo copyediting, typesetting, and review of the resulting proof before it is published in its final form. Please note that during the production process errors may be discovered which could affect the content, and all legal disclaimers that apply to the journal pertain. 


\section{Highlights:}

- Radiators in both old and new houses are often over-dimensioned

- Low-temperature heating could be used for most of the year already today

- Expected energy renovations will also facilitate low-temperature heating

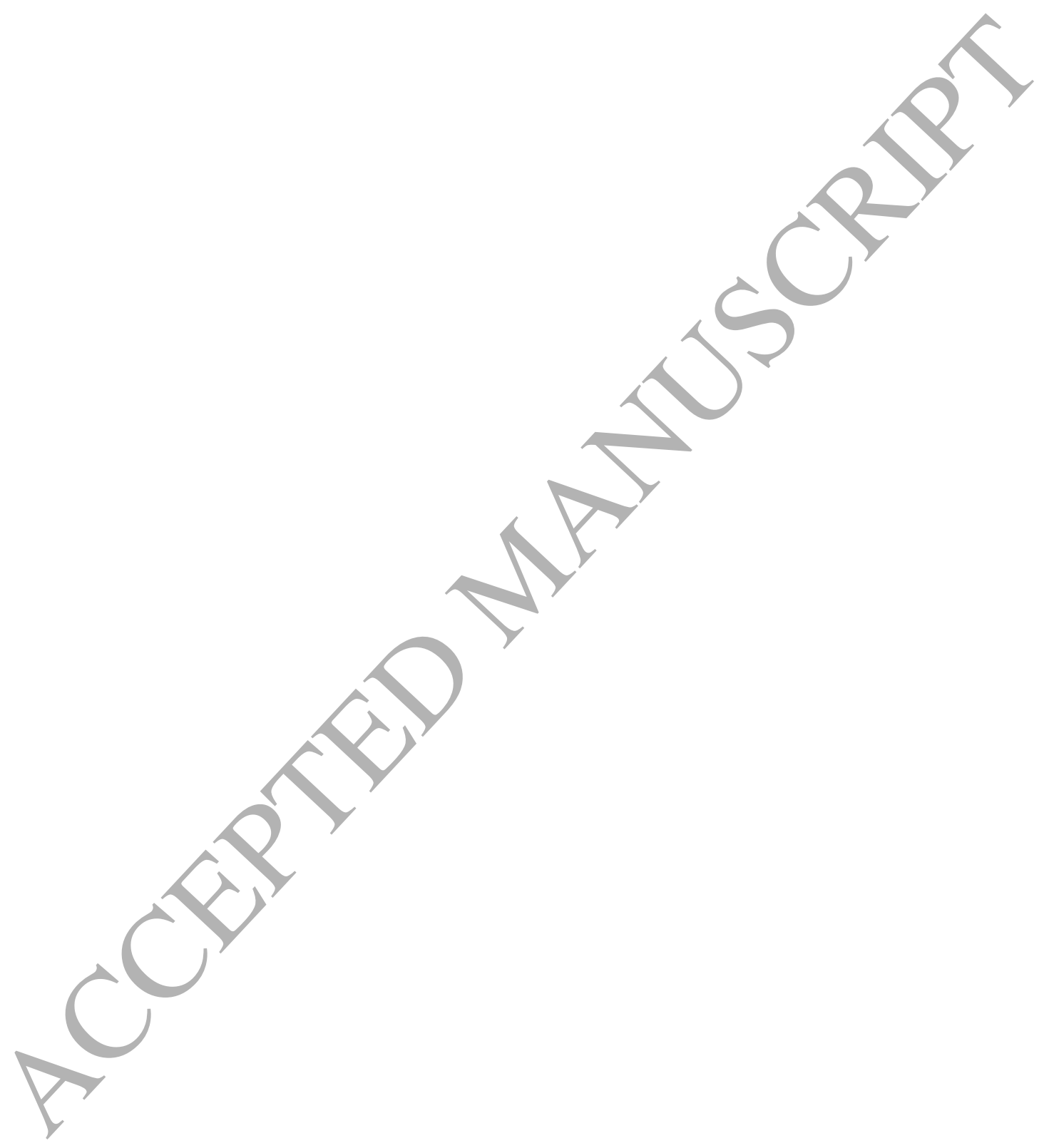


Are typical radiators over-dimensioned? An analysis of radiator dimensions in 1645 Danish houses

Dorte Skaarup Østergaard*, Svend Svendsen

*Corresponding author, Tel. +45 422518 80, E-mail address: dskla@byg.dtu.dk.

Technical University of Denmark, Department of Civil Engineering, Brovej, Building 118, DK-2800 Kgs. Lyngby, Denmark.

\section{Declarations of interest: none}

\section{Abstract}

This study analyses the heat load in a total of 11,584 rooms in 1645 Danish houses and the heat output of the radiators in them to evaluate whether typical radiators are over-dimensioned. The aim was to find out whether radiators in existing houses are suited for low-temperature district heating. We found that new houses are generally more likely to have over-dimensioned radiators, though the heat output of the radiators installed varies a great deal. We also found that many old houses can be equally fit for lowtemperature district heating, especially if they have been through some energy renovation. Our results show that approximately $80 \%$ of heating systems are over-dimensioned relative to their current design heat load. This share will rise to about $92 \%$ as expected energy renovations are carried out towards 2050 . Houses with currently over-dimensioned heating systems can be heated with supply temperatures below $60{ }^{\circ} \mathrm{C}$ for most of the year. Due to extreme design conditions, even under-dimensioned heating systems can be operated with low temperatures for much of the year, although slightly higher supply and/or return temperatures would have to be accepted.

Keywords: Low-temperature district heating, low-temperature space heating, design heat output, design heating demand, space heating systems, 


\section{Nomenclature}

$\mathrm{n}=$ Radiator exponent $[-]$

$\mathrm{Q}_{\text {annual }}=$ Annual heating consumption $\left[\mathrm{kWh} / \mathrm{m}^{2}\right]$

$\mathrm{T}_{\mathrm{e}}=$ Exterior temperature $\left[{ }^{\circ} \mathrm{C}\right]$

$\mathrm{T}_{\mathrm{i}}=$ Indoor temperature $\left[{ }^{\circ} \mathrm{C}\right]$

$\mathrm{T}_{\mathrm{r}}=$ Radiator return temperature $\left[{ }^{\circ} \mathrm{C}\right]$

$\mathrm{T}_{\mathrm{s}}=$ Radiator supply temperature $\left[{ }^{\circ} \mathrm{C}\right]$

$\mathrm{U}_{\text {house }}=$ Thermal transmittance pr. floor area of house under steady state $\left[\mathrm{W} / \mathrm{m}^{2} \mathrm{~K}\right]$

$\Delta \mathrm{T}_{\mathrm{log}}=$ Logarithmic mean temperature difference $\left[{ }^{\circ} \mathrm{C}\right]$

$\Delta \mathrm{T}_{\text {log,design }}=$ Logarithmic mean temperature difference at design temperatures $\left[{ }^{\circ} \mathrm{C}\right]$

$\Phi_{\text {design,load }}=$ Design heat load, total $[\mathrm{W}]$ or per floor area $\left[\mathrm{W} / \mathrm{m}^{2}\right]$

$\Phi_{\text {design,output }}=$ Heat output of radiators at design temperatures, total $[\mathrm{W}]$ or per floor area $\left[\mathrm{W} / \mathrm{m}^{2}\right]$

$\Phi_{\text {load }}=$ Heat load, total $[\mathrm{W}]$ or per floor area $\left[\mathrm{W} / \mathrm{m}^{2}\right]$

$\Phi_{\text {output }}=$ Heat output of radiators at chosen temperatures, total $[\mathrm{W}]$ or per floor area $\left[\mathrm{W} / \mathrm{m}^{2}\right]$ 


\section{Introduction}

The building sector accounts for some $40 \%$ of all energy consumption in the $\mathrm{EU}$ and by far the largest share of this energy consumption is for heating [1]. If we are to reduce fossil fuel consumption and avoid excessive climate change, there is therefore a great need to improve the energy efficiency of our heating systems.

One way of improving the energy efficiency of the heating sector is to reduce the supply and return temperatures for space heating. In the case of buildings heated with district heating, the main benefit from reduced temperatures is the increased efficiency of heat production from sources such as solar heating, geothermal heating, and boilers with flue gas condensation. Low heating-system temperatures are also very important for heat pumps, where the efficiency depends greatly on the temperatures. For example, Ploskić and Holmberg [2] have shown that operating a heating system with supply and return temperatures of $40{ }^{\circ} \mathrm{C} / 30{ }^{\circ} \mathrm{C}$ instead of $55{ }^{\circ} \mathrm{C} / 45^{\circ} \mathrm{C}$ can improve heat pump efficiency by up to $25 \%$ and thus reduce $\mathrm{CO}_{2}$ emissions from heating by up to $24 \%$. In a review, Ovchinnikov et al. [3] report additional benefits from low-temperature heating, including reduced heat losses from distribution systems in multi-family buildings [4] and improved thermal comfort [5].

New buildings can easily be designed for low-temperature space heating, and the general trend in building regulations is towards lower design temperatures $[3,6,7]$. However, existing buildings make up the majority of the current building stock, and existing heating elements were often designed for higher temperatures. This could be a problem because the heat output of a radiator is reduced when the heating-system temperatures are reduced. On the other hand, several studies indicate that most current heating systems are over-dimensioned, meaning that the radiator sizes are so large, that the heat output of the radiators is greater than is needed to cover the heat loads in the rooms. One reason for this is that common design methods are either based on rough rules of thumb or extreme design conditions with no internal heat gains and extremely low outdoor temperatures. An example of this is reported in a study by Hasan et al. [8] who conclude that modern Finnish buildings could be well-suited for low-temperature heating due to the initial 
over-sizing of radiators using typical design methods. Moreover, several studies indicate that existing heating systems could be operated with temperatures lower than those expected, which can also be explained by the fact that the heating systems are over-dimensioned. These studies include Jangsten et al. [9] and Averfalk et al. [7], who have reported the heating system temperatures in several Swiss and Swedish heating systems, and Tunzi et al. [10], who have shown that heating-system temperatures in existing houses could be greatly optimized during actual operation.

Another reason that heating systems in existing buildings tend to be over-dimensioned is that the heat load in many buildings has been reduced through energy renovation. This was found in a theoretical investigation the current authors carried out on the expected heat output in existing Danish single-family houses [11]. Moreover, studies by Wang et al. [12], Brand et al, [13], and Harrestrup et al. [14] all indicate that typical existing buildings can be heated with low temperatures if they have been through energy renovation. Most of these reported findings, however, are based on case studies, theoretical considerations, or general experience, and although it is commonly noted that radiators are often oversized $[6,12,15,16]$, cases with under-dimensioned radiators have also been encountered $[17,18]$.

To the best of the authors' knowledge, no large-scale study has previously been made to demonstrate that actual radiator sizes in existing buildings are in general over-sized. This is supported by the findings of a recent European study that concludes that there is a general lack of knowledge about heating-system temperatures and heating systems inside existing buildings [7]. The current study therefore set out to produce new knowledge about the typical dimensions of radiators in existing Danish houses based on actual data from a large survey. Such knowledge is crucial for the future transition to low-temperature heating, because large savings can be achieved with very little investment if heating systems are in fact currently over-dimensioned and appropriate for low-temperature supply already today. 


\subsection{Aim of study}

The aim of this study was to generate new knowledge about the heat output of radiators installed in existing houses, based on actual survey data. An analysis of the dimensioning of existing heating systems was carried out by comparing survey data on the heat load and the total heat output in existing Danish houses. Analyses were made to see if factors such as the age of the house and the energy efficiency of the building had an impact on the estimated total heat output. Secondly, the expected supply and return temperatures during the year were calculated for three different dimensions of heating system. The purpose of this was to illustrate how an under-dimensioning of the heating system would affect the potential for reducing the supply and return temperatures in the houses. The supply and return temperature strategies suggested here were based on heat supply from a district heating network, though other strategies could be applied based on other options for heat supply.

\section{$2 \quad$ Method}

This study consisted of two parts: an investigation of a large number of observations of the total heat output and the heat load in 1645 houses, and an investigation of actual heating system operating temperatures in houses with three different radiator dimensions. The following sections describe the methods applied in the two investigations.

\subsection{Description of survey data}

The main analyses in this paper/are of estimated heat load and total heat output based on observations in approximately 11,600 rooms of Danish single-family houses and small apartment buildings. The observations were registered by plumbers performing service checks on heating system installations in houses supplied by district heating. The plumbers recorded the following information for each house (1-3) and for each room in the house (4-6):

1. Construction year (range: 1620-2014)

2. Geographical location (Danish postal code, which indicates a town or area)

3. Estimated design heat load (range: $20-150 \mathrm{~W} / \mathrm{m}^{2}$ floor area) 
4. Estimated design heat output of radiators [W]

5. Floor area $\left[\mathrm{m}^{2}\right]$

6. Type of room [kitchen, bedroom, living room, dining room, bathroom, etc.]

The estimation of the design heat load is based on the plumber's individual evaluation of the state of the building construction. This evaluation was typically carried out by starting from a table of typical heat loads for houses based on their construction year, and then reducing the expected heat load by the savings expected from identified energy renovations carried out, such as the replacement of windows or extra insulation added on the roof. The design heat load was therefore an estimated average for the house as a whole, and used for every room without adjustment for the individual room's external wall areas or window sizes.

The heat output of the radiators was estimated based on radiator type and heating surface area using a tool that calculates the heat emissions from typical Danish radiators. In rooms that contained more than one radiator, each radiator was included as an individual observation, and the total room area was split in proportion to the heat output of the individual radiator. This means that some rooms count as two rooms.

\subsection{Pre-processing and overview of data}

All the data was entered manually by the plumbers, and it was then checked for misprints and obvious mistakes before use in the analysis. During this pre-processing, the following types of observation record were excluded from the dataset:

- Records with unreasonable input values or likely misprints (e.g. a design radiator heat output of $0.06 \mathrm{~W}$ or a non-existent postal code)

- Records where important parameters (floor area, radiator heat output, heat load) were missing

- Records for rooms without a radiator (e.g. non-heated rooms - often hallways, sculleries, or basement rooms) or rooms that were heated by electrical heating or floor heating 
- Records for houses with only one room (or two rooms, if it looked as if the data were incomplete or significantly non-typical)

The data was also slightly pre-processed in order to focus the analysis on the radiator sizes. For example, additional electrical heating (such as floor heating or towel rails in bathrooms) was ignored. In some cases observations of radiators had been noted without further room information. In this case, the radiator heat output was attributed to the room of the previous observation, because we assumed that the record represented a case of a room with more than one radiator.

To achieve an overview of the data and limit variation in the output, the processed data were grouped by construction period, geographical area, and heat load. The grouping of data by construction period was based on the typical construction periods defined in the Danish contribution to the European TABULA study of typical building constructions [19]. The distribution of observations across the various periods is shown in Fig. 1 (left) and was found to correspond well with the average distribution of single-family houses in Denmark, where a large number of houses were built during a building boom in 1960-1980 (groups 5-6) and in the period 1900-1950 (included in groups 2-3). The geographical grouping was based on six geographical areas in Denmark (Greater Copenhagen, Zealand, Funen, Southern Jutland, Mid Jutland, and Northern Jutland), as shown in Fig. 1 (right). Most of the observations were made in Zealand and in the Copenhagen area, while Funen and Southern Jutland were generally under-represented. However we do not think this had much effect on the results, because building customs are fairly similar in the various parts of the country. 


\section{Rooms according to construction year}

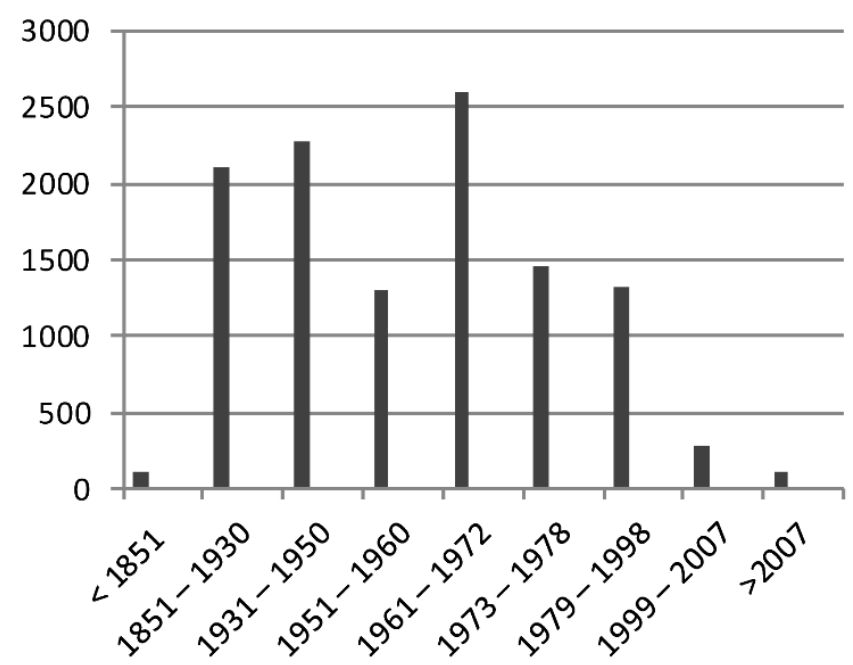

DENMARK

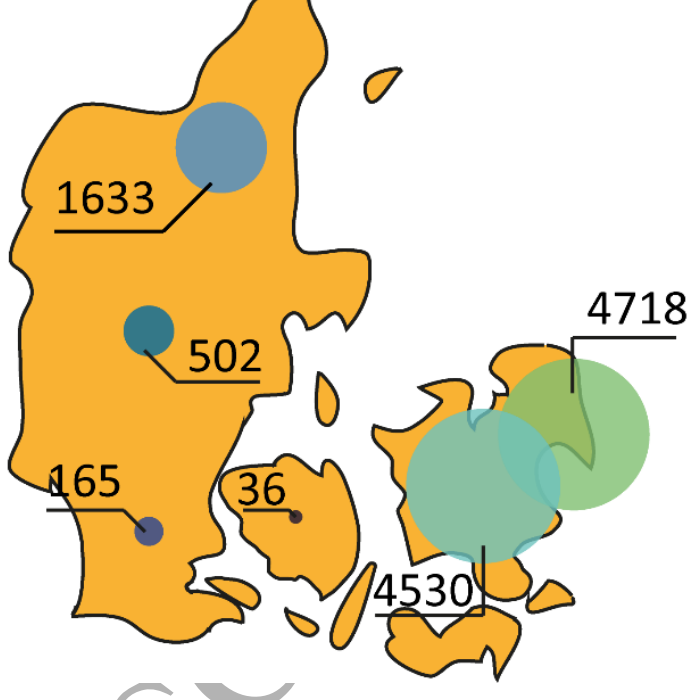

Fig. 1 Distribution of observations by construction period (left) and geographical location (right).

Due to the large amount of data, it was not possible to investigate all the input data in detail. Apart from the above-mentioned pre-processing of the data, it was therefore assumed that the observations were generally reliable.

\subsection{Over-dimensioned radiators}

The dimensioning of a heating system can be done in many ways, and discussion of whether a heating system is over-dimensioned requires a definition of the dimensions expected. A heating system could be over-dimensioned for the actual operation conditions, over-dimensioned relative to the dimensioning standards current at the time of the building's erection, or over-dimensioned compared to today's dimensioning standards. Furthermore, a heating system can be deliberately over-dimensioned in order to take into account rapid re-heating periods after night set-backs or vacations. In this study, we only considered the usual steady operation of the heating system, and our aim was to investigate whether the heat output of the radiators installed in existing houses is large enough to allow the use of low-temperature heating. We therefore considered whether the total heat output of the existing heating system could cover the existing design heat load of the houses using reasonably modern supply and return temperatures. Over-dimensioning in this study was therefore defined as follows: 
The heating system is defined as over-dimensioned when: the design heat output of the heating system at the supply and return temperatures of $70^{\circ} \mathrm{C} / 40^{\circ} \mathrm{C}$ is above the current design heat load of the heated building.

Supply and return temperatures of $70^{\circ} \mathrm{C} / 40^{\circ} \mathrm{C}$ were commonly used in Denmark for a long period in the late 1900 s $[7,11]$. This is therefore a common temperature set referred to for a large part of the existing building stock in Denmark. Moreover, it is close to the current Danish design temperatures of $60^{\circ} \mathrm{C} / 40^{\circ} \mathrm{C}$. In Denmark, the design heat load is the heat load required to maintain an indoor temperature of $20^{\circ} \mathrm{C}$, when the outdoor temperature is $-12{ }^{\circ} \mathrm{C}$ and no heat gains are taken into account.

We investigated the question of over-dimensioned radiators by adding an extra parameter to the data set the radiator factor. The factor describes the relationship between the design heat output of the heating system and the design heat load of the building. It was calculated for each house as a whole. It did not make sense to investigate this at room level because the estimated heat load of each room was not differentiated according to the external wall area and window area.

The radiator factor was calculated in the following way. First the design heat output was converted to the typical Danish temperature set with supply and return temperatures of $70^{\circ} \mathrm{C}$ and $40{ }^{\circ} \mathrm{C}$ respectively. Most of recorded heat output data were already given at these temperatures, while a few were given at different temperature sets. The conversion was performed in accordance with Equation 1 and Equation 2, which are prescribed in current standards for the calculation of the heat output of radiators $[20,21]$. The equations are derived empirically to provide a simplification for calculations of the non-linear relationship between heat output and the temperature difference between radiator and the surrounding air [22], and they were applied using the logarithmic mean temperature difference and a standard radiator exponent of 1.3 , as suggested in Danish guidelines [20].

Equation $1 \quad \Phi_{\text {output }}=\Phi_{\text {design,output }} \cdot\left(\frac{\Delta T \operatorname{Tlog}}{\Delta T \log _{\text {design }}}\right)^{n}$

where 
$\Phi_{\text {output }}$ is the total heat output of the radiators at the chosen temperatures 70/40/20 [W]

$\Phi_{\text {design, output }}$ is the total heat output of the radiators at design temperatures [W]

$\Delta T l o g$ is the logarithmic mean temperature difference at the chosen temperatures $70 / 40 / 20\left[{ }^{\circ} \mathrm{C}\right]$

$\Delta \operatorname{Tlog}_{\text {design }}$ is the logarithmic mean temperature difference at design temperatures $\left[{ }^{\circ} \mathrm{C}\right]$

$n$ is the radiator exponent

Equation $2 \quad \Delta \operatorname{Tlog}=\frac{\left(T_{s}-T_{r}\right)}{L N\left(\frac{T_{s}-T_{i}}{T_{r}-T_{i}}\right)}$

where

$T_{s}$ is the supply temperature

$T_{r}$ is the return temperature

$T_{i}$ is the indoor air temperature

Secondly, the design heat output values for all the radiators in the house were summed and divided by the total heated room area of the house to obtain the design heat output in $\mathrm{W}$ per $\mathrm{m}^{2}$ floor area. Lastly, the radiator factor was calculated by dividing the design heat output of the house by the estimated design heat load of the house, as shown in Equation 3.

Equation $3 \quad$ Radiator factor $=\frac{\Phi_{\text {design,output }}}{\Phi_{\text {design,load }}}$

where

$\Phi_{\text {design,output }}$ is the total design heat output of the radiators in $W$ per $\mathrm{m}^{2}$ heated floor area

$\Phi_{\text {design,load }}$ is the design heat load of the house in $W$ per $m^{2}$ heated floor area

The radiator factor thus indicates whether the radiators are over- or under-dimensioned (above or below 1 respectively).

\subsection{Annual heating demands}

The insulation standard of modern buildings can often be evaluated in terms of the annual heating demand, so we made estimations of the annual heating demands corresponding to the various design heat loads. These were calculated using the degree-day method, as given in Equation 4. First, the design heat load was divided by the design temperature difference to estimate the heat loss related to the temperature difference between indoors and outdoors in the design situation. In Denmark, the design indoor temperature is $20^{\circ} \mathrm{C}$ while the design outdoor temperature is $-12{ }^{\circ} \mathrm{C}$. Second, this value was multiplied by the number of degree days for a normal year. The degree days are calculated by calculating the difference 
between the average daily outdoor temperature and an indoor temperature of $17^{\circ} \mathrm{C}$. This is done for all days where outdoor temperatures are below $17^{\circ} \mathrm{C}$ and summed for the entire year. Finally, the value is multiplied by 24 and divided by 1000 to convert the unit to $\mathrm{kWh}$. In these calculations, we applied a standard degree-day number for Denmark of $2808^{\circ} \mathrm{C} /$ year [23].

Equation $4 \quad Q_{\text {annual }}=\frac{\Phi_{\text {design,load }}}{T_{i, \text { design }}-T_{e, \text { design }}} \cdot D D \cdot 24 / 1000$

where

$Q_{\text {annual }}$ is the annual heating demand per heated floor area $\left[\mathrm{kWh} / \mathrm{m}^{2}\right]$

$\Phi_{\text {design,load }}$ is the design heat load of the house $\left[\mathrm{W} / \mathrm{m}^{2}\right]$

$T_{i, \text { design }}$ is the design indoor temperature of $20^{\circ} \mathrm{C}$

$T_{e, \text { design }}$ is the design exterior temperature of $-12{ }^{\circ} \mathrm{C}$

$D D$ is the number of degree days, here $2808^{\circ} \mathrm{C} /$ year

\subsection{Energy renovations}

To make it possible to evaluate whether the insulation standard of the houses would have an influence on the feasibility of shifting to low-temperature heating, the houses were divided into three categories according to their estimated design heat load. The grouping is illustrated in Table 1. Please note, that the category with the best insulation still has an estimated annual heating demand which is far higher than expected for typical modern low-energy houses.

Table 1 Grouping of houses according to insulation standard

\begin{tabular}{|l|l|l|l|}
\hline Insulation level & Poor insulation & Medium insulation & Good insulation \\
\hline Design heating demand & Above $85 \mathrm{~W} / \mathrm{m}^{2}$ & $55-85 \mathrm{~W} / \mathrm{m}^{2}$ & Below $55 \mathrm{~W} / \mathrm{m}^{2}$ \\
\hline $\begin{array}{l}\text { Estimated annual } \\
\text { heating demand }\end{array}$ & Above $179 \mathrm{kWh} / \mathrm{m}^{2}$ & $116-179 \mathrm{kWh} / \mathrm{m}^{2}$ & Below $116 \mathrm{kWh} / \mathrm{m}^{2}$ \\
\hline
\end{tabular}

In the years to come, the existing building stock is expected to go through energy renovation either as part of general maintenance or due to energy policies to reduce heat consumption. According to the Danish Building Research Institute, the energy renovations expected for typical Danish houses will lead to typical design heat loads below $60 \mathrm{~W} / \mathrm{m}^{2}$ [19]. When the heat load is reduced, the share of over-dimensioned heating systems will increase. The effect of such renovations was investigated by calculating the radiator 
factor for the buildings in the data sample, assuming that the design heat load of each house was reduced to a maximum of $60 \mathrm{~W} / \mathrm{m}^{2}$.

\section{6}

\subsection{Heating system operation temperatures}

Even if the heating system is under-dimensioned and the radiator factor is found to be below 1 , the heating system can still be operated with low temperatures for most of the year. This is because the calculated radiator factor only refers to the design situation with extreme outdoor temperatures and no heat gains. Actual operation conditions are very different, because typical outdoor temperatures are much higher than $-12{ }^{\circ} \mathrm{C}$ and Danish standards suggest a typical internal heat gain of $5 \mathrm{~W} / \mathrm{m}^{2}$ from occupants and equipment. Typical heating system supply and return temperatures that would be applicable in typical Danish houses during the course of a year were therefore calculated for a theoretical house with a medium design heat load of $75 \mathrm{~W} / \mathrm{m}^{2}$ and a correctly dimensioned or under-dimensioned heating system (radiator factors of 1 , 0.8 , and 0.6 respectively). The calculations were carried out as follows:

The heat demand in the house was assumed to be linearly related to the difference between indoor and outdoor temperatures. The heat transmission coefficient of the house was therefore first calculated based on Equation 5.

\section{Equation 5}

$$
U_{\text {house }}=\frac{\Phi_{\text {design,load }}}{T_{i, \text { design }}-T_{e, \text { design }}}
$$

where

$U_{\text {house }}$ is the heat transmission coefficient of the house per $\mathrm{m}^{2}$ heated floor area $\left[\mathrm{W} / \mathrm{m}^{2} \mathrm{~K}\right]$

$\Phi_{\text {design,load }}$ is the design heat load of the house in $\mathrm{W}$ per $\mathrm{m}^{2}$ heated floor area (here $75 \mathrm{~W} / \mathrm{m}^{2}$ )

$T_{i, \text { design }}$ is the design indoor temperature of $20^{\circ} \mathrm{C}$

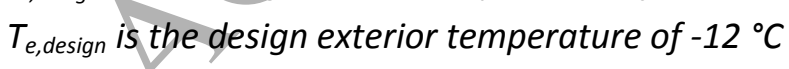

The heat loads of the house at typical exterior temperatures $\left(T_{e}\right)$ between $-5{ }^{\circ} \mathrm{C}$ and $15^{\circ} \mathrm{C}$ were then calculated in accordance with Equation 6, by using the heat transmission coefficient and taking internal heat gains of $5 \mathrm{~W} / \mathrm{m}^{2}$ into account. For the typical heating system operation, we assumed that the actual 
indoor temperature is maintained at $21{ }^{\circ} \mathrm{C}$ throughout the year, which has been found to be more realistic than $20^{\circ} \mathrm{C}$ for current Scandinavian homes [24].

Equation $6 \quad \Phi_{\text {load }}=U_{\text {house }} \cdot\left(T_{i, a c t u a l}-T_{e}\right)-5 \mathrm{~W} / \mathrm{m}^{2}$

where

$\Phi_{\text {load }}$ is the heat load of the house at various outdoor temperatures in $W$ per $m^{2}$ heated floor area

$T_{i, a c t u a l}$ is the assumed actual indoor temperature of $21^{\circ} \mathrm{C}$

$T_{e}$ is the exterior temperature varying between $-5^{\circ} \mathrm{C}$ and $15^{\circ} \mathrm{C}$.

The heating systems investigated were assumed to have a radiator factor of $1.0,0.8$, or 0.6 . The design heat output of the heating system was therefore assumed to be $100 \%, 80 \%$, or $60 \%$ of the design heat load of $75 \mathrm{~W} / \mathrm{m}^{2}$.

To calculate the heating system supply and return temperatures needed, we first calculated the logarithmic mean temperature difference needed to cover the heat load at the varying outdoor temperatures. This was done using Equation 1 and Equation 2. Finally, we calculated the supply and return temperature needed to meet the logarithmic mean temperature difference required. This was done through an iterative process using Equation 2. Supply and return temperatures were varied to obtain the logarithmic mean temperature difference required to maintain an indoor temperature of $21^{\circ} \mathrm{C}$. The supply and return temperatures were calculated for two different strategies - a return temperature strategy and a supply temperature strategy. These strategies are described in Table 2. The strategies suggested are based on heat supplied from a district heating network, so they take into account the special requirements for cooling in a district heating system. Other temperature strategies can be designed for other heat supply options, because both condensing gas-boilers and heat pumps also benefit from low-temperature operation, or to take into account other local district heating temperature preferences.

Table 2 Description of return temperature strategy and supply temperature strategy for a district heating scenario

\begin{tabular}{|l|l|l|}
\hline & Return temperature strategy & Supply temperature strategy \\
\hline Aim & $\begin{array}{l}\text { To achieve a return temperature as low as } \\
\text { possible }\end{array}$ & $\begin{array}{l}\text { To use a supply temperature that is as low } \\
\text { as possible. }\end{array}$ \\
\hline Motivation & A reduction in return temperature provides & A low supply temperature is very beneficial \\
\hline
\end{tabular}




\begin{tabular}{|c|c|c|}
\hline & $\begin{array}{l}\text { increased energy efficiency for current } \\
\text { heating production with biomass boilers or } \\
\text { waste incineration with flue gas } \\
\text { condensation. }\end{array}$ & $\begin{array}{l}\text { in the case of heat supplied from e.g. a } \\
\text { heat pump }\end{array}$ \\
\hline Conditions & $\begin{array}{l}\text { A supply temperature of at least } 65^{\circ} \mathrm{C} \text { is } \\
\text { available from the district heating network } \\
\text { due to high temperature requirements of } \\
\text { some buildings and old domestic hot water } \\
\text { tanks. }\end{array}$ & $\begin{array}{l}\text { A district heating supply temperature of at } \\
\text { least } 55^{\circ} \mathrm{C}\left(50^{\circ} \mathrm{C} \text { in secondary systems) for }\right. \\
\text { the safe delivery of domestic hot water } \\
\text { through instantaneous heat exchangers } \\
\text { without risk of legionella. } \\
\text { At least } 30^{\circ} \mathrm{C} \text { cooling of the district heating } \\
\text { water in winter due to capacity limitations } \\
\text { in the district heating pipes. }\end{array}$ \\
\hline
\end{tabular}

\section{$3 \quad$ Results and discussion}

\subsection{Survey results}

Fig. 2 shows a box plot of the total heat output installed in the houses surveyed, grouped by construction period. For comparison, Fig. 3 shows a box plot of the estimated design heat load or annual heating demand of the houses included in the survey. As shown in Fig. 2, the boxes in both plots represent the 25, 50 , and 75 percentiles of the houses, while the error margins show the minimum of the top $5 \%$ and the maximum of the bottom $5 \%$ of the houses.

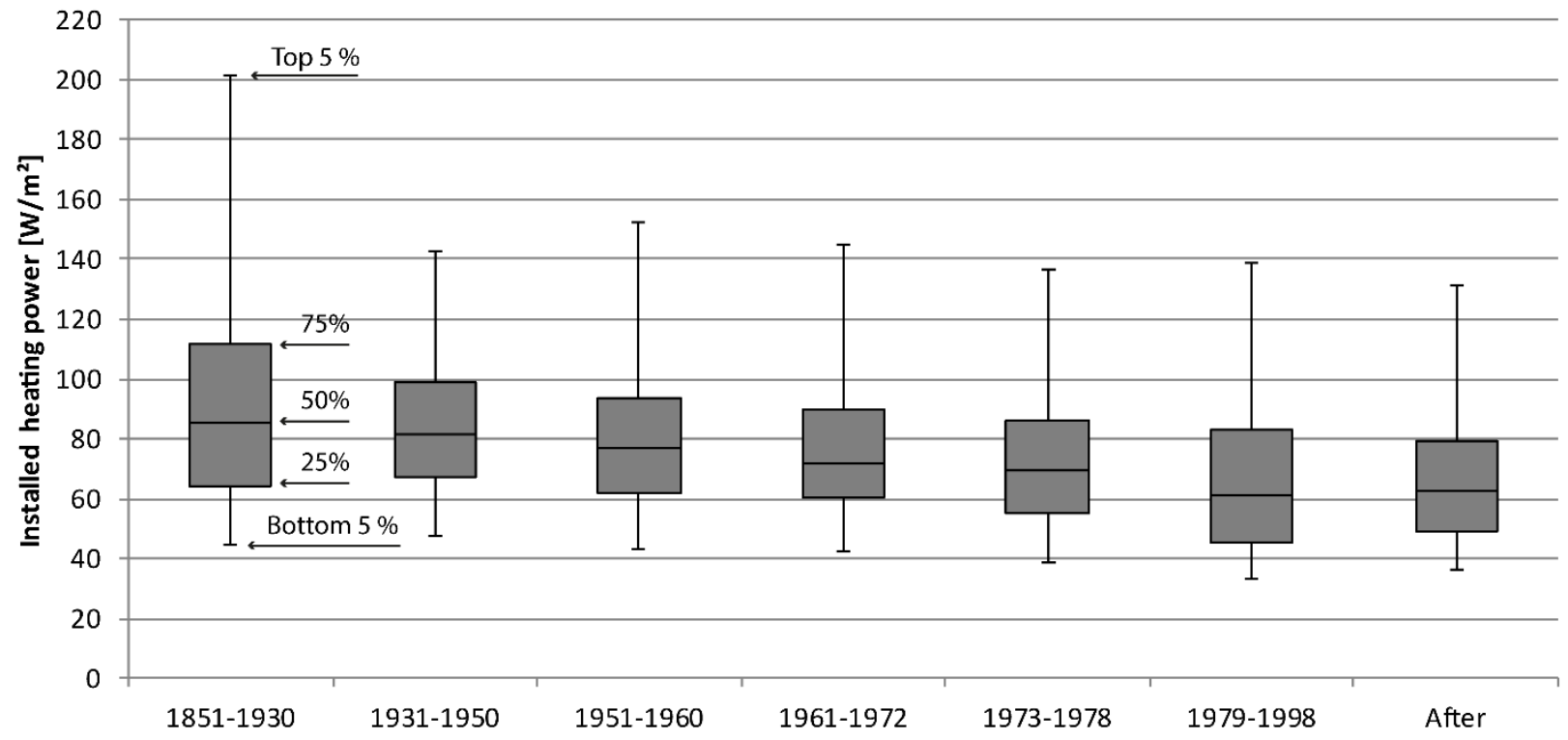

Fig. 2 Boxplot of the total heat output (in $\mathrm{W} / \mathrm{m}^{2}$ of heated floor area) installed in 1645 Danish houses. The heat output is given at supply and return temperatures of $70^{\circ} \mathrm{C}$ and $40^{\circ} \mathrm{C}$ respectively. 


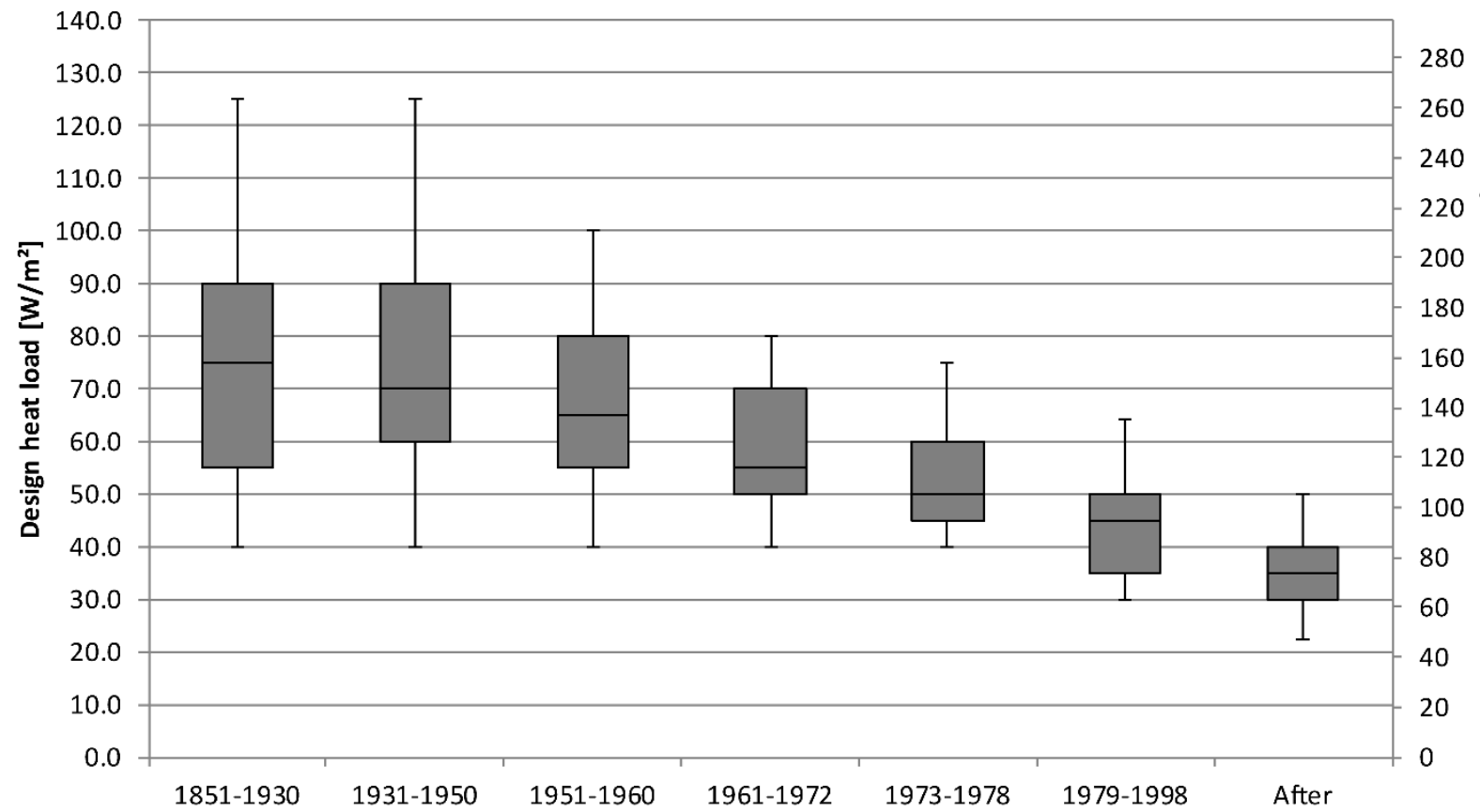

Fig. 3 The design heat load or annual heating demand of the houses included in the survey

The results show that new houses tend to have less design heat output installed. This is not surprising, because the heating demand is also lower in new houses, and radiators can therefore be expected to be designed to cover this lower demand. The results also show a large variation in the heat output installed in individual houses. While perhaps not so surprising in older houses, where the heating systems may have been designed at different points in time and in accordance with different guidelines, the reader might have expected that the total heat output installed in newer houses would deviate less due to standardized heating system design procedures and strict regulations on design heat load.

Fig. 4 shows a box-plot of the radiator factor in the houses surveyed, grouped by construction period. 


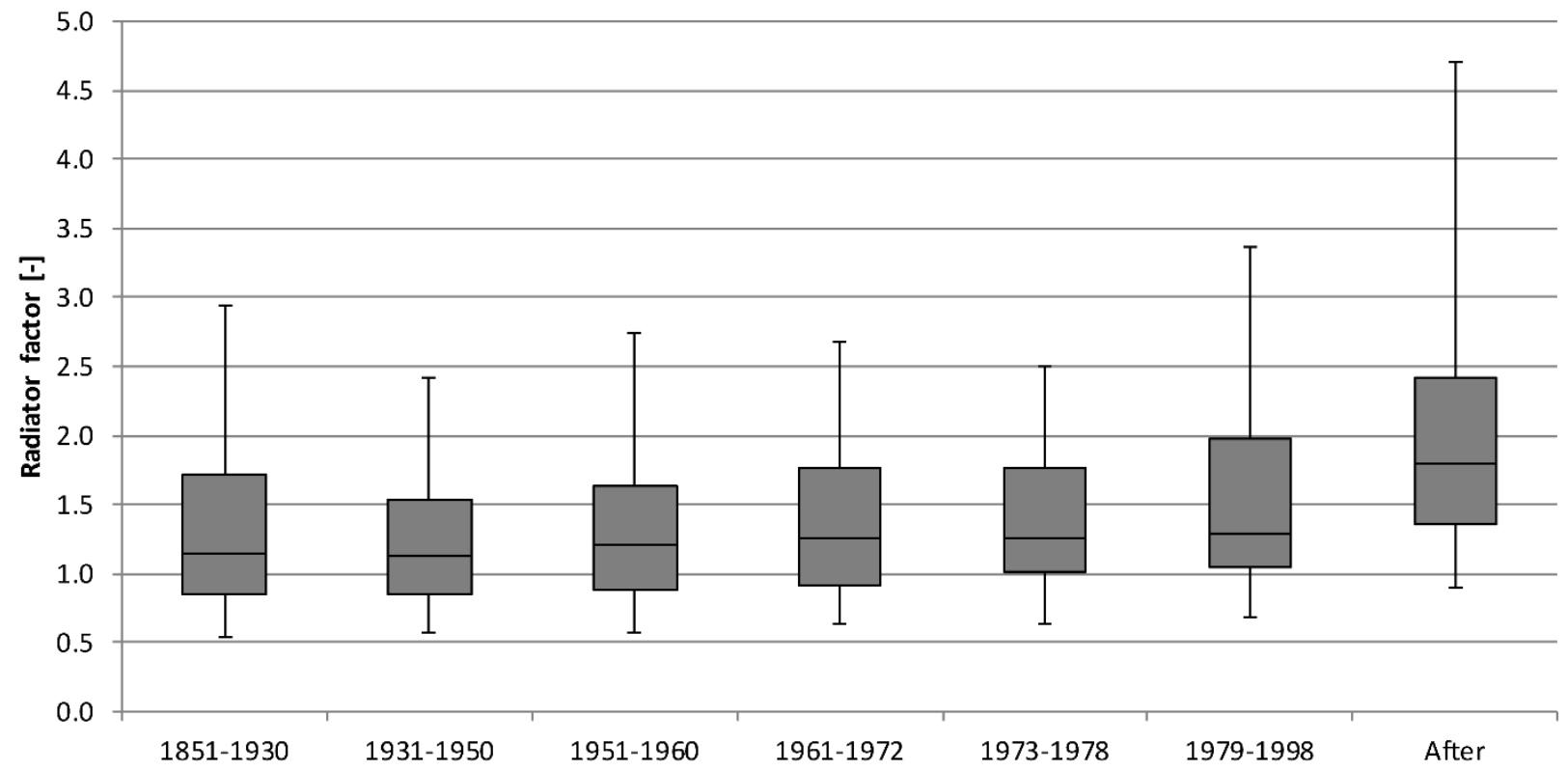

Fig. 4 The radiator factor for 1645 houses, grouped by construction period

The figure shows that the vast majority of heating systems are over-dimensioned relative to their estimated current design heat loads (with radiator factors between 1.0 and 4.5 ), while a small minority of the heating systems are slightly under-dimensioned (with radiator factors between 0.5 and 1.0). The figure also shows that the radiator factor of the houses is higher for new houses, especially for those built after 1998. This could be partly due to decreasing design heating-system temperatures that lead to new heating systems being made larger in size. This would indicate that it may be easier to heat new houses with lowtemperature heating, since heating systems in new houses are more likely to be over-dimensioned. The figure shows that a very small percentage of houses constructed after 1972 have a radiator factor below 1.0, while more than $25 \%$ of the houses built before 1973 have a radiator factor below 1.0. Nevertheless, the figure also shows that an older house from 1930 may be just as easy to heat with low heating-system supply temperatures as a new house, because more than $50 \%$ of old houses also have a radiator factor of 1.1 or above.

\subsection{Radiator factor and energy renovations}

Fig. 5 shows a box-plot of the radiator factor in the houses, grouped by heat consumption. 


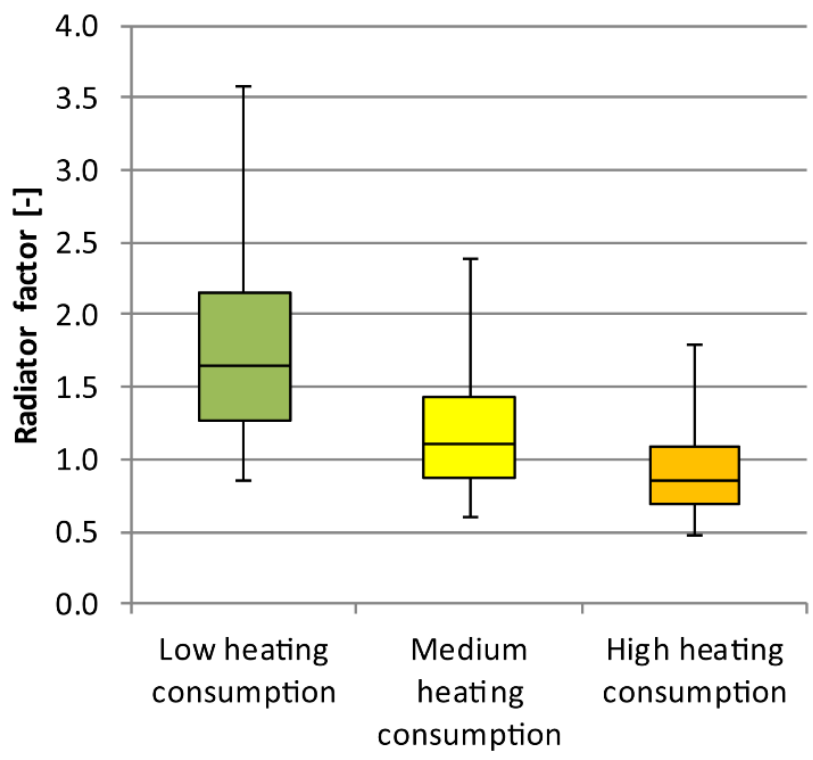

Fig. 5 The radiator factor in the houses, grouped by heating consumption

The figure shows that houses with a low design heat load are more likely to have over-dimensioned radiators. This is both because the insulation of the thermal envelope of the existing buildings has been improved and because new buildings, which were found to be more likely to have over-dimensioned radiators, generally belong to the group with low heating consumption.

Fig. 6 shows the percentage of heating systems that are over-dimensioned according to the current status of the houses surveyed (black line) and according to a scenario where all houses have been renovated to meet a maximum design heat load of $60 \mathrm{~W} / \mathrm{m}^{2}$ (green dashed line). 


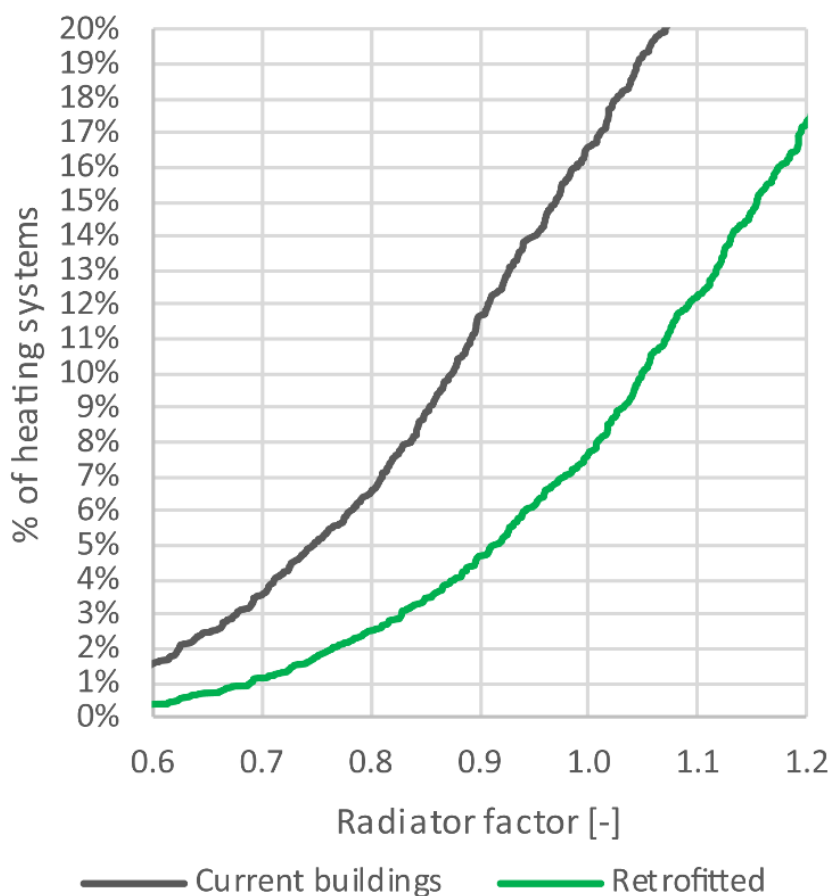

Fig. 6 Percentage of heating systems with a radiator factor between 0.6 and 1.2.

The graph shows that approximately $17 \%$ of the heating systems surveyed currently have a radiator factor below 1.0. If the houses are renovated, this percentage will be reduced to approximately $8 \%$. Moreover, this does not mean that $8 \%$ of all radiators will need to be replaced before low-temperature heating can be used - as we will show in the next sections.

\subsection{Actual heating-system temperatures}

Even if some rooms have heating elements that are under-dimensioned relative to the design conditions (as illustrated by the radiator factor), they can be still over-dimensioned relative to the actual heating demand, which may differ greatly from the design situation. Fig. 7 and Fig. 8 give examples of supply and return temperature curves from a house with a medium heating consumption (a design heat load of 75 $\mathrm{W} / \mathrm{m}^{2}$ ) and a heating system with a radiator factor of $0.6,0.8$, or 1.0.

Fig. 7 shows the supply and return temperatures that would apply in a scenario where medium supply temperatures are available, and the supply temperature is therefore chosen with a view to achieving a low return temperature. 


\section{Return temperature strategy}

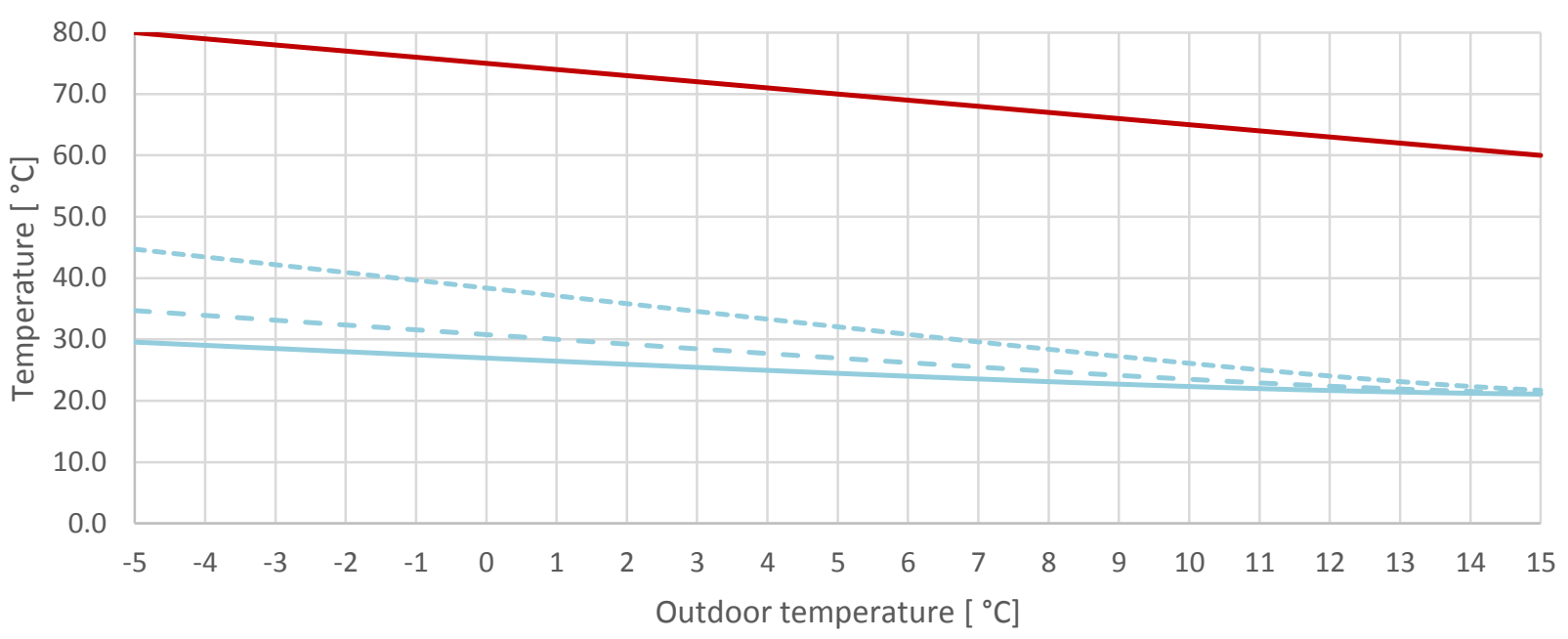

- Supply

- Return $1.0 \quad---$ Return $0.8 \quad-----$ Return 0.6

Fig. 7 Supply and return temperature curves for a house with a radiator factor of $0.6,0.8$, or 1.0 optimized for a low return temperature

As the figure shows, a heating system that is under-dimensioned by $40 \%$ causes the return temperature from the house to increase by up to $15^{\circ} \mathrm{C}$ in cold periods. A house with a radiator factor of 1.0 would be able to deliver return temperatures below $30^{\circ} \mathrm{C}$ for most of the year if a high heating system supply temperature is accepted. It can though be argued that lower heating supply temperatures would be preferable to avoid the risk of scalding on pipes and radiator surfaces.

Fig. 8 shows the supply and return temperatures that would apply in a scenario where temperatures are chosen with a view to achieving a low supply temperature. 


\section{Supply temperature strategy}

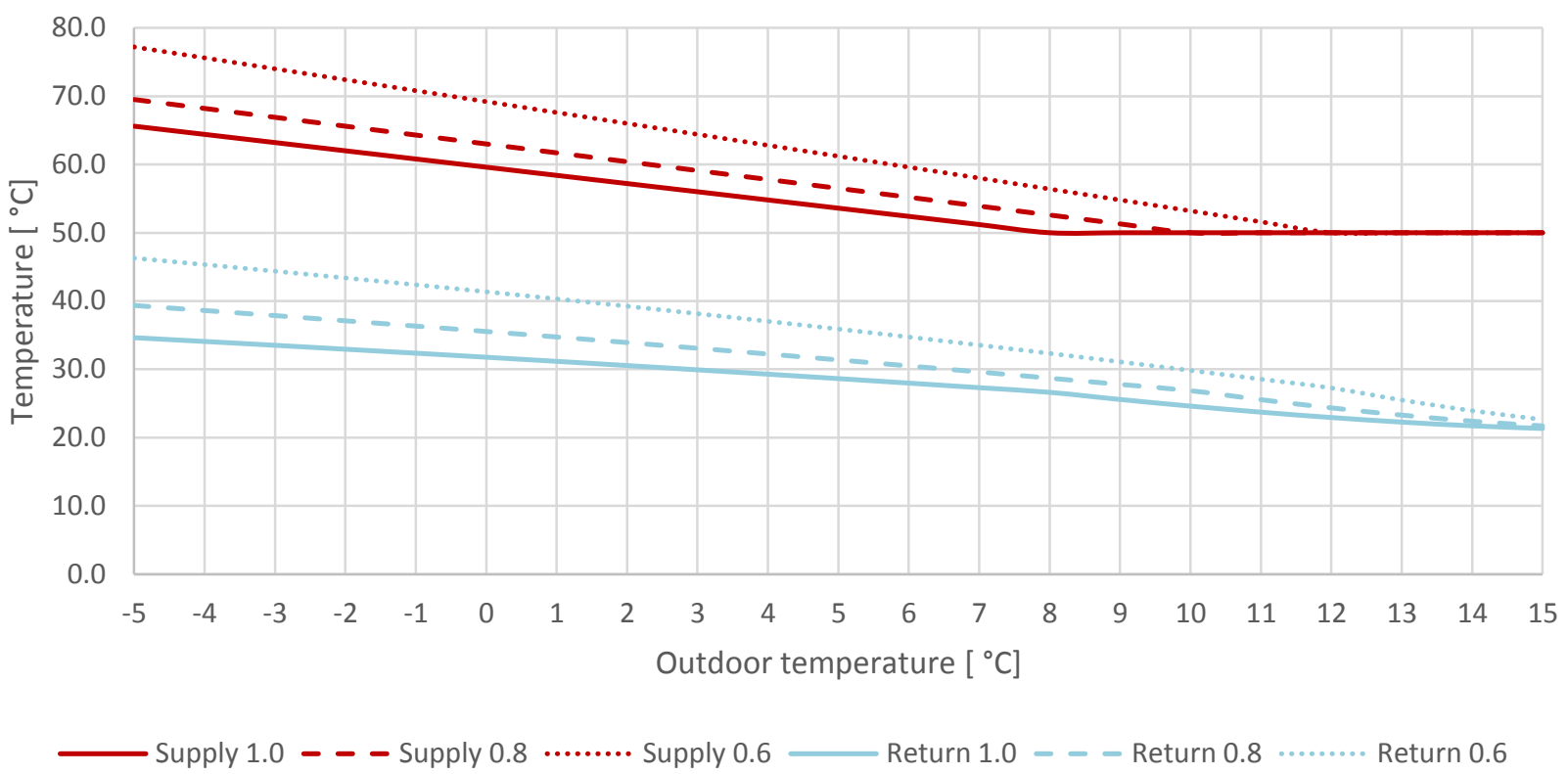

Fig. 8 Supply and return temperature curves for a house with a radiator factor of $0.6,0.8$, or 1.0 optimized for a low supply temperature

As the figure shows, if a house has a heating system with a radiator factor of 0.6 instead of 1.0 , the supply temperature needs to be increased by about $12^{\circ} \mathrm{C}$ in cold periods. However, even if the supply temperature is not increased in this way, occupants will probably have no problem maintaining thermal comfort. It would just have to be accepted that the return temperature from houses with radiator factors below 1.0 will need to be somewhat higher to maintain the required mean temperature difference of the radiator. As the figure shows, supply temperatures can be as low as $65^{\circ} \mathrm{C}$ in the heating system (about 70 ${ }^{\circ} \mathrm{C}$ in the district heating network) in cold periods, if the existing houses have a heating system with a radiator factor of 1.0 or higher.

\section{4}

\section{Comparison with other studies}

To investigate the accuracy of the survey data, the estimated design heat load and installed heat output were compared with the findings of earlier studies. Fig. 9 shows a comparison of the annual heating demands calculated for the houses included in this study and the values found for Danish houses according to their energy labels [19]. As the figure shows, the average estimated annual heating demands of the 
houses in this study might be slightly under-estimated compared to the results of the energy labels. However, the deviation between the two sets of data is still rather small, and all in all, the data of this survey seems reasonable.

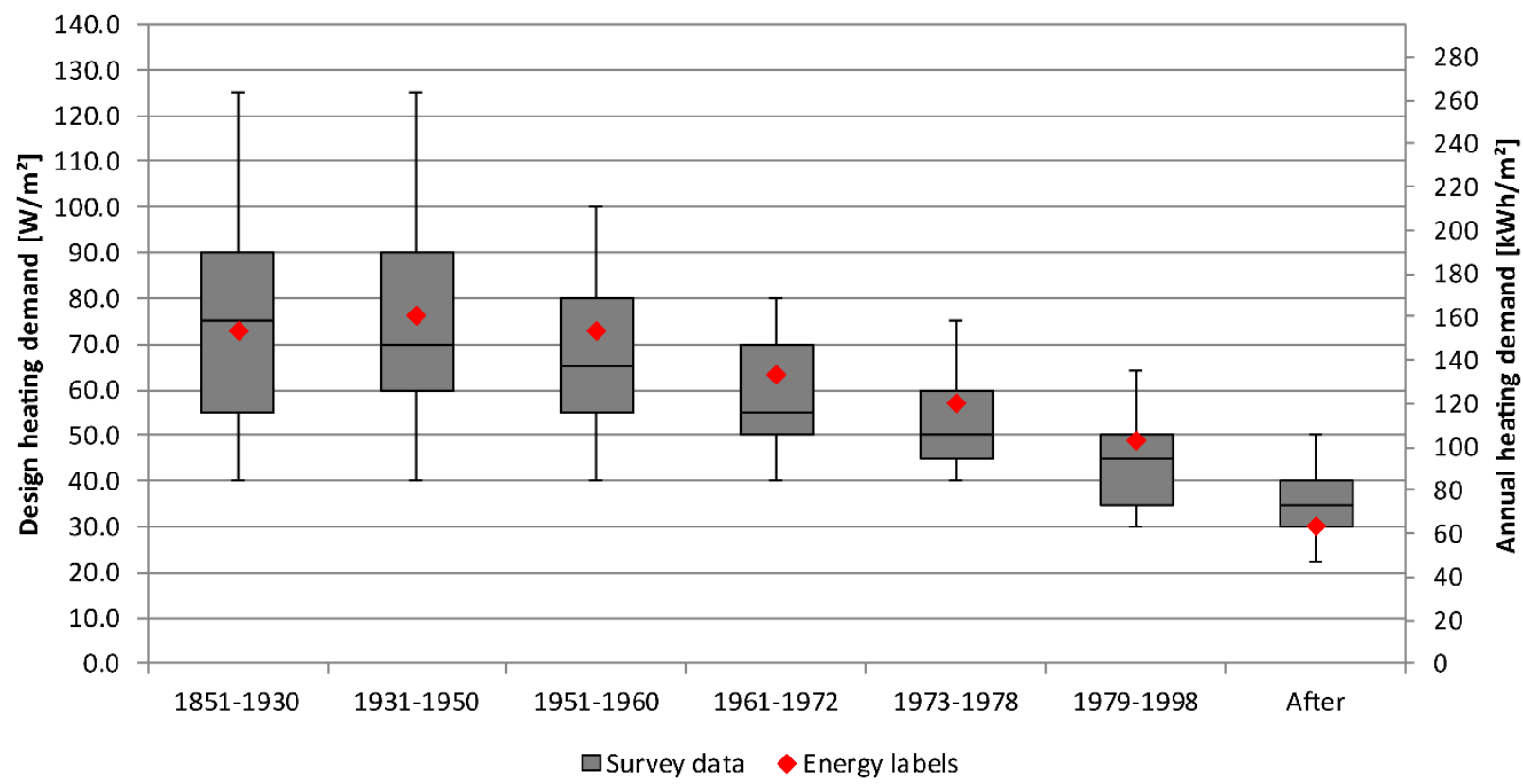

Fig. 9 Comparison of the heating demand estimated in the current survey with that found in a previous study of Danish houses [19]

Fig. 10 shows a comparison of the estimated total heat output according to the current study with our own expectations in our theoretical findings in previous work [11]. The figure shows that the findings of this study indicate that existing houses have a slightly higher installed heat output than we expected in our theoretical estimate. This difference could be explained by the fact that the theoretical estimate was based on a single case house which may therefore not be representative of the average of the houses included in the survey. The difference between the studies could also be because many house-owners have modified their heating system since the erection of the house, so that the actual heat output differs from the theoretical estimate. Nevertheless, the comparisons could indicate that the results from the survey tend to slightly over-estimate the radiator factor of existing houses. 


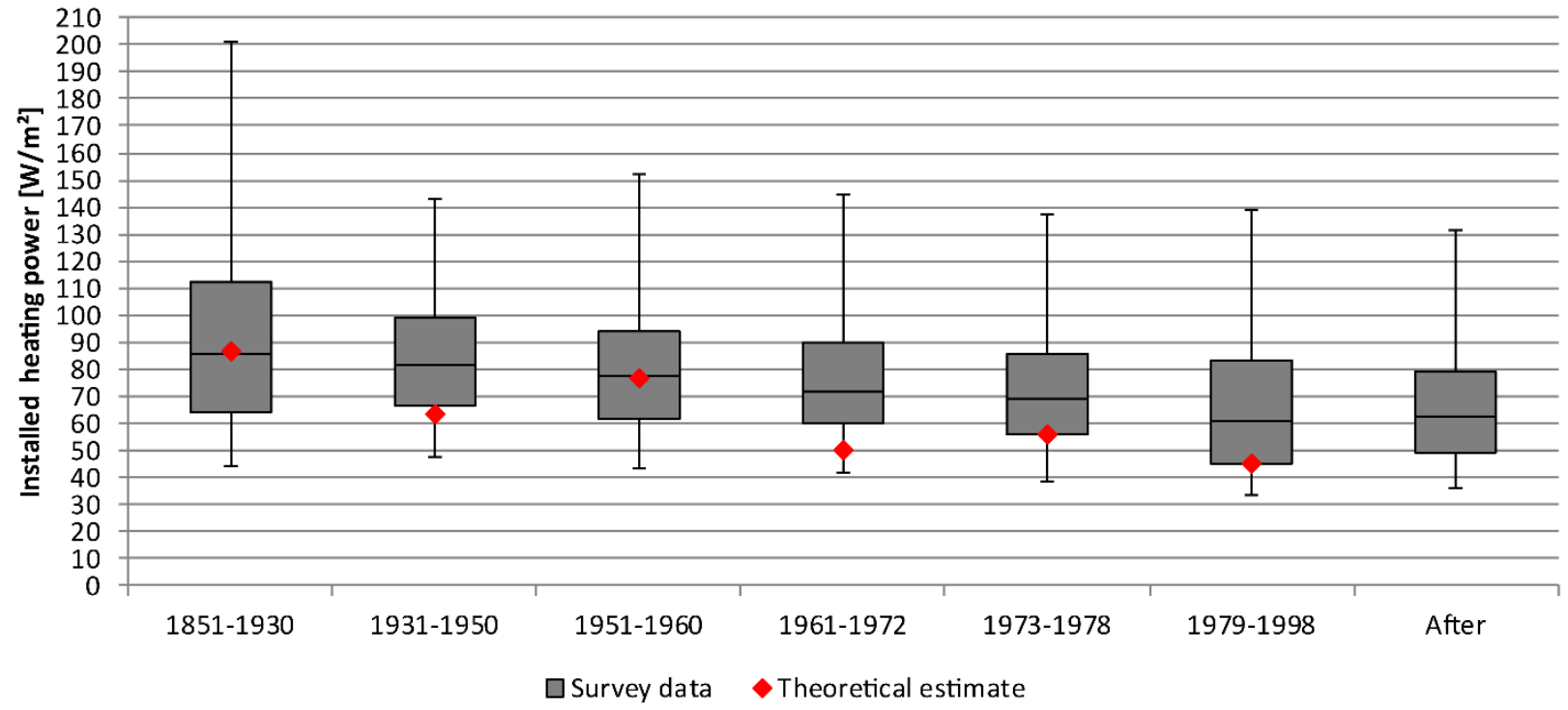

Fig. 10 Boxplot of total installed heat output $\left(70^{\circ} \mathrm{C} / 40^{\circ} \mathrm{C}\right)$ in 1645 Danish houses compared with our own previous theoretical estimate [11].

\section{$5 \quad$ Uncertainties}

This study set out to investigate the total heat output installed and the heating system dimensions typical of existing Danish houses. While this provides an indication of the potential for using low-temperature heating in the existing building stock, it does not give any information on how this potential can be realised. To make full use of the heat output of the radiators installed, both the heating system and the individual heat producing units must be properly controlled and operated.

Due to the uncertainties in the survey data presented, we do not recommend relying on individual data points or minimum/maximum measurements. The findings of this study are based on data that was estimated and manually recorded by plumbers, which will unavoidably have included some errors and misprints. So, although the recorded data was checked and pre-processed, it is impossible to be sure that it was correctly estimated and recorded. Nevertheless, the average measurements can still provide useful information, because the investigation included data from 1645 houses, which will reduce the effect of errors in some of the individual records. So, even if the results are not $100 \%$ accurate, we think they 
provide a good indication of the actual state of heating systems in Danish houses, and this view is supported by the comparisons with other existing data in section 4 .

One large draw-back of the study lies in the fact that the heat output was investigated for each house as a whole and not on a room-by-room basis. In reality, the total heating system consists of a number of radiators heating individual rooms in the houses and every radiator has to be large enough to meet the heating demand of the given room. So, even if the results of this study show that a number of houses have a radiator factor below 1.0 , this does not necessarily mean that all the radiators in these houses are underdimensioned. And just because the results of this study show that many houses have a high radiator factor, this does not necessarily mean that all the radiators in these houses are large enough to meet thermal comfort preferences in all rooms, when operated with low heating system temperatures. Previous studies by the current authors have found that the replacement of just a few critical radiators in houses with under-dimensioned heating systems is often enough to ensure that the heating system can be operated with low-temperature heating [25]. This suggests that the replacement of a relatively small number of radiators in houses with under-dimensioned heating systems will make it possible for all houses to be operated with the same low supply temperatures.

The results presented in this study were based on two slightly conservative estimates. Firstly, all additional electrical floor heating was ignored in the study. Additional electrical heating will supply extra heat output, which will reduce the number of under-dimensioned heating systems. Secondly, the supply and return temperature strategies illustrated were calculated by using the logarithmic mean temperature difference and a standard radiator exponent of 1.3. This method is known to slightly underestimate the heat output of typical radiators. On the other hand, the study did not include non-heated rooms in the analysis. If these were included, the total heat output installed per floor area would be slightly lower. Furthermore, the supply and return temperature strategies suggested in this study are based on the possibility of maintaining an indoor temperature of $21^{\circ} \mathrm{C}$ in all rooms. This temperature may be somewhat higher in some rooms and 
somewhat lower in others, depending on occupant preferences. If higher indoor air temperatures are to be maintained, which seems indicated by recent trends, heating systems will need larger dimensions to ensure that the same temperature strategies can be utilized.

Since the results presented are evidently prone to some uncertainties, they should only be used to provide an indication of the state of the total heat output installed and heating system dimensions in typical existing Danish houses. The temperature profiles presented are intended to illustrate how low-temperature district heating can be used even in houses with under-dimensioned heating systems. Nevertheless, the actual temperatures in the individual houses will vary. If this study does in fact slightly over-estimate the radiator factor of existing houses, as indicated by the comparison with other sources, then the number of houses that need slightly higher heating system temperatures will be higher. On the other hand, the results of this study showed that the majority of existing heating systems are greatly over-dimensioned, and they can therefore be operated with much lower heating system temperatures than those presented in this study. In conclusion, low-temperature heating will be able to ensure proper thermal comfort in all houses, even without replacing any radiators, though it would mean that somewhat higher return temperatures would have to be accepted in houses with a low radiator factor.

\section{Conclusions}

This study set out to provide a factual basis to support the general statement that existing radiator heating systems are over-dimensioned and illustrate the potential for reducing heating-system temperatures in existing houses.

The results of the study show that most radiator heating systems are over-dimensioned in the sense that the estimated design heat output of the heating systems at supply and return temperatures of $70^{\circ} \mathrm{C}$ and 40 ${ }^{\circ} \mathrm{C}$ is greater than the estimated design heat load. The results indicate that the newer the house and the smaller the heat load, the more likely it is that the heating system is over-dimensioned. This suggests that 
the potential for low-temperature heating is greatest in areas with newer houses or houses that have gone through a reasonable amount of energy renovation.

The results of the study show that there is a big potential for low-temperature district heating to heat houses with properly dimensioned or over-dimensioned heating systems. For houses with underdimensioned heating systems, slightly higher supply and or return temperatures must be accepted, but since these houses comprise only a small portion of the total building stock, they may only have a small impact on the overall district heating system. As long as district heating pipe dimensions allow it, it is therefore possible to reduce district heating temperatures even though a few houses have underdimensioned heating systems. Replacing all the radiators in existing houses in preparation for lowtemperature heating would not only be very expensive, but is unnecessary. Nevertheless, further research should be carried out on the energy efficiency improvements that could be achieved in district heating systems by replacing critical radiators in the $8 \%$ of houses that can still be expected to have underdimensioned heating systems when the time comes for low-temperature district heating.

\section{Acknowledgements}

The work presented in this article was a result of the activities of the Strategic Research Centre for 4th Generation District Heating (4DH), which received funding from Innovation Fund Denmark. A special thankyou is due to Fjernvarmens Serviceordning, which provided the survey data that made this study possible. 


\section{References}

[1] European Commission. Buildings (n.d.) https://ec.europa.eu/energy/en/topics/energyefficiency/buildings (accessed July 18, 2018).

[2] Ploskić A, Holmberg S. Heat emission from thermal skirting boards. Build Environ 2010;45:1123-33.

[3] Ovchinnikov P, Borodinecs A, Millers R. Utilization potential of low temperature hydronic space heating systems in Russia. J Build Eng 2017;13:1-10. doi:10.1016/j.jobe.2017.07.003.

[4] Maivel M, Kurnitski J. Low temperature radiator heating distribution and emission efficiency in residential buildings. Energy Build 2014;69:224-36. doi:10.1016/j.enbuild.2013.10.030.

[5] Hesaraki A, Ploskic A, Holmberg S. Integrating Low-temperature Heating Systems into Energy Efficient Buildings. Energy Procedia 2015;78:3043-8. doi:10.1016/j.egypro.2015.11.720.

[6] Lauenburg P. Improved supply of district heat to hydronic space heating systems. PhD thesis, Lund University, Sweden; 2009.

[7] Averfalk H, Werner S, Felsmann C, Rühling K, Wiltshire R, Svendsen S, et al. Annex XI final report: Transformation Roadmap from High to Low Temperature District Heating Systems. IEA; 2017.

[8] Hasan A, Kurnitski J, Jokiranta K. A combined low temperature water heating system consisting of radiators and floor heating. Energy Build 2009;41:470-9. doi:10.1016/j.enbuild.2008.11.016.

[9] Jangsten M, Kensby J, Dalenbäck JO, Trüschel A. Survey of radiator temperatures in buildings supplied by district heating. Energy 2017;137:292-301. doi:10.1016/j.energy.2017.07.017.

[10] Tunzi M, Østergaard DS, Svendsen S, Boukhanouf R, Cooper E. Method to investigate and plan the application of low temperature district heating to existing hydraulic radiator systems in existing buildings. Energy 2016;113:413-21. doi:10.1016/j.energy.2016.07.033.

[11] Østergaard DS, Svendsen S. Theoretical overview of heating power and necessary heating supply temperatures in typical Danish single-family houses from the 1900s. Energy Build 2016;126:375-83.

[12] Wang Q, Ploskić A, Holmberg S. Retrofitting with low-temperature heating to achieve energydemand savings and thermal comfort. Energy Build 2015;109:217-29. doi:10.1016/j.enbuild.2015.09.047.

[13] Brand M, Svendsen S. Renewable-based low-temperature district heating for existing buildings in various stages of refurbishment. Energy 2013;62:311-9. doi:10.1016/j.energy.2013.09.027.

[14] Harrestrup M, Svendsen S. Changes in heat load profile of typical Danish multi-storey buildings when energy-renovated and supplied with low-temperature district heating. Int J Sustain Energy 2013;34:232-47. doi:10.1080/14786451.2013.848863.

[15] Trüschel A. Hydronic heating systems - the effect of design on system sensitivity. PhD thesis, Chalmers University of Technology, Göteborg, Sweden; 2002.

[16] Skagestad B, Mildenstein P. District heating and cooling connection handbook. NOVEM, Netherlands Agency for Energy and the Environment; 2002.

[17] Danish Energy Agency, EUDP 2008-II. CO2-reductions in low energy buildings and communities by implementation of low-temperature district heating systems. Demonstration cases in 
EnergyFlexHouse and Boligforeningen Ringgården - Journalnr. 63011-0152. DTU BYG: 2011.

[18] Andersen NB, Grimmig M. Lavtemperaturvarme i Eksisterende Boliger [Low-temperature heating in existing homes]. The Danish Technological Institute; 1988.

[19] Wittchen KB, Kragh J. Danish building typologies - participation in the TABULA project. Danish Building Research Institute; 2012.

[20] Danish Building Research Institute. Varmeanlæg med vand som medium [Hydraulic heating systems] - SBi-anvisning 175. 2000.

[21] Danish Standard - CEN/TC 130. DS/EN 442-2 - Radiators and convectors - Part 2: Test methods and rating. 2014.

[22] Goettling DR. Heat emission rates of hydronic terminal elements and their relastionship to heating cost allocation devices. ASHRAE Trans Symp 1993;99:888-98.

[23] Christensen K. Varmeanlæg - undervisningsnotat [Heating systems - Teaching note]. 2003.

[24] Frederiksen S, Werner S. District heating and cooling. Studentlitteratur; 2013.

[25] Østergaard DS, Svendsen S. Replacing critical radiators to increase the potential to use lowtemperature district heating - A case study of 4 Danish single-family houses from the 1930s. Energy 2016;110:75-84. doi:10.1016/j.energy.2016.03.140. 